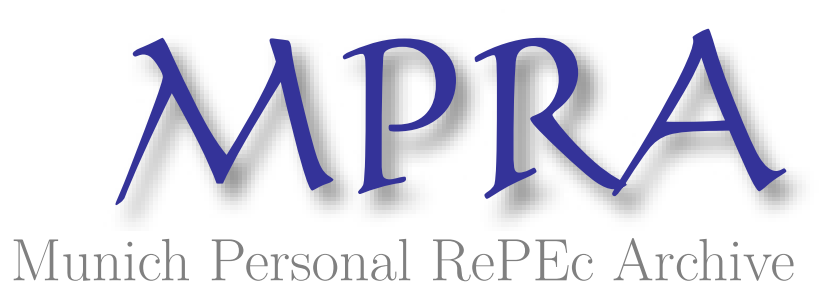

\title{
Aid Effectiveness Disputed
}

Hansen, Henrik and Tarp, Finn

1999

Online at https://mpra.ub.uni-muenchen.de/62290/

MPRA Paper No. 62290, posted 03 Mar 2015 15:01 UTC 


\title{
AID EFFECTIVENESS DISPUTED
}

\author{
by
}

\author{
Henrik Hansen and Finn Tarp ${ }^{1}$
}

\begin{abstract}
There is a widespread perception among academic researchers and aid practitioners alike that empirical cross-country analysis fails to find any significant link between aid flows and growth, and that aid is successful only when associated with good policies in the recipient countries. These positions do not stand up to careful scrutiny of existing studies. In this paper, we offer a re-examination of the literature on the aidsavings, aid-investment, and aid-growth relationships, and a comparative appraisal of more recent research contributions. Using an analytic framework for evaluating the empirical work, a coherent and positive picture of the aid-growth link emerges. Aid works, even in countries hampered by an unfavourable policy environment.
\end{abstract}

\section{Introduction}

The past 30 years have witnessed a massive outpouring of studies on the effectiveness of foreign aid. The topic has been a central and recurring theme with which many economists, subscribing to the different paradigms of development thinking, have grappled. The question of whether aid works or not has been approached from different methodological and ideological perspectives. More specifically: (i) the impact of aid has been evaluated at both the micro- and macroeconomic level; (ii) cross-country as well as single-country case studies have been relied on; and (iii) aid effectiveness research includes broad surveys of a qualitative and inter-disciplinary nature as well as quantitative analyses. A comprehensive survey of the aid effectiveness literature is not feasible in this paper. ${ }^{2}$ Instead we will address, in some detail, a particularly thorny issue that has preoccupied aid-protagonists and aid-critics alike, namely the macroeconomic impact of aid on growth.

The choice of focus can be justified on several grounds. First, the existing literature lacks a strong analytical framework, which can be used to compare and evaluate the causal

\footnotetext{
${ }^{1}$ Sherman Robinson provided extensive comments and drafting suggestions on earlier versions on this paper. They are gratefully acknowledged. The same goes for discussions with Irma Adelman and Erik Thorbecke among many others, who helped shape the approach adopted. Useful comments were also received from Gerry Helleiner and participants in three seminars at the University of California (Berkeley), Cornell University, and the International Food Policy Research Institute (IFPRI). Research assistance provided by Steen Asmussen, Henning Tarp Jensen and Søren Vikkelsø is appreciated. The usual caveats apply.

2 The reader may wish to consult Cassen and associates (1994) for a useful survey with a broader scope than the present paper.
} 
relationships in the various studies. Aid is given for many different purposes and in many different forms. From an analytical perspective, one can draw on both traditional growth theory and new growth models to illustrate how aid can potentially impact on economic growth through a highly diverse set of channels. For example, Cassen and associates (1994) argue that there is plenty of evidence to substantiate that development projects have often yielded respectable economic rates of return; and this is so in spite of the disappointment with the project mode of operation. Similarly, numerous case studies support the World Bank (1998) observation that aid has, at times, been a spectacular success. It is neither analytically defensible nor empirically credible to argue from the outset that aid never works. A more constructive point of departure requires focussed questions and well specified empirical hypotheses. The impact of aid on selected macroeconomic variables, including in particular savings, investment, and growth, incorporates such a set of specific and testable propositions, and it is in any case desirable to explore the impact of aid in a wider macroeconomic setting.

Moreover, there is a need to resolve one of the most stubborn paradoxes in the aid effectiveness literature. This is the widespread perception that a contradiction exists between the results of microeconomic and macroeconomic studies. Available literature surveys on the macroeconomic impact of aid covering the period up to the end of the 1980s tell a much less sanguine story than microeconomic project evaluations. Reviewers have found it difficult to generalise, and it is regularly argued that the traditional cross-country empirical work has failed to provide statistically significant insights. Michalopoulos and Sukhatme (1989) conclude that the cross-country evidence is ambiguous, and White (1992a) asserts that we know surprisingly little about aid's macroeconomic impact. He goes on to argue that the absence of a relationship between aid and growth is a fairly well established result. The seeming lack of a positive macroeconomic impact of aid in combination with the many favourable micro-based project evaluations is a puzzle. Mosley (1987) named it the micro-macro paradox.

The perceived lack of evidence on the macroeconomic effects of aid has generally been blurred by an associated critique of the econometric methodology applied. The conclusions drawn by Michalopoulos and Sukhatme (1989) as well as White (1992a) have been particularly influential in shaping the common view of the aid-growth linkages. Yet, these surveys concentrate on the conceptual, econometric, and data difficulties involved in crosscountry analyses. While these difficulties must certainly be kept in mind, little guidance is provided in this work on whether empirical results (i.e., the signs of critical parameters, their statistical significance, and their policy implications) are either robust or consistent with analytical models of the links between aid and growth.

A re-examination of the macroeconomic impact of aid is pertinent for other reasons as well. Debate has recently erupted once again following the cross-country regressions by Boone (1994, 1996) and Burnside and Dollar (1997). These studies are much cited contributions. In the colourful language of the Economist, Boone's work is claimed to show that aid is "down the rathole" (December 10, 1994). The Burnside-Dollar results are reviewed (November 14, 1998) under the heading "making aid work", and it is noted that aid will 
only work if it is spent on the right countries with low inflation, small budget deficits, openness to trade, strong rule of law, and a competent bureaucracy.

In this survey we consider three generations of empirical cross-country work on aid effectiveness. We delineate the analytical underpinnings of each generation and provide an encyclopaedic survey of work in each. In this manner, we arrive at the conclusion that existing literature supports the proposition that aid improves economic performance. There is no micro-macro paradox to resolve, not even in countries hampered by an unfavourable policy environment.

Throughout the underlying premise is that whether aid is effective or not is an empirical question. This is not to say that theory, ranging from the early Harrod-Domar to the new growth models, has been without influence in shaping the reduced form specification of empirical relations estimated. On the contrary, theory has over the years played an important role in influencing both the perceptions about how aid impacts on growth and the necessary conditions that must be in place for this impact to be positive. Nevertheless, it is fair to observe as shown in, say, Barro and Sala-i-Martin (1995) and Aghion and Howitt (1998), that the growth process depends on an intricate range of interacting characteristics and lines of influence. The growth process cannot be fully captured in simple analytical frameworks. By implication, the same can be said for the macroeconomic impact of aid. While this may be discouraging to the purist, we try to demonstrate that useful insights can still be gained from the specifications adopted in the empirical cross-country literature and the results hereof when proper care is taken to do this in a coherent analytical framework.

\section{Aid, Savings, and Growth: First-Generation Studies}

In the early literature on aid and growth in less developed countries, foreign aid was perceived only as an exogenous net increment to the capital stock of the recipient country. It was assumed by pro-aid development economists such as Rosenstein-Rodan (1961) that each dollar of foreign resources in the form of aid would result in an increase of one dollar in total savings and investment. In other words, aid was not treated as a component of national income adding to both consumption and investment. Hence, fungibility of aid resources was not allowed for, and aid for consumption purposes was skipped over in this type of macroeconomic aid impact analysis.

The theoretical workhorse underlying this empirical work is the Harrod-Domar growth model with the causal chain running from aid to savings to investment to growth. Papanek (1972) characterised the highly optimistic aid-impact approach embedded in the HarrodDomar theoretical growth model as "curiously naive". At the same time, he forcefully

\footnotetext{
${ }^{3}$ Papanek (1972) also pointed out carefully that some aspects of the simple Harrod-Domar model were modified in the Chenery-Strout-Bruno two-gap model (e.g., Chenery and Strout, 1966), which in his view greatly increased analytical sophistication and connection with reality. Import capacity was introduced as a separate potential constraint on growth, and the incremental capital-output ratio did not remain fixed. Yet, the assumptions about the contribution of foreign resources were not changed. It was maintained that they were exactly additive to domestic savings and domestically financed imports.
} 
countered the arguments put forward in the late 1960s by Griffin (1970) and Griffin and Enos (1970). They held a sceptical view of aid and argued that "The association is loose, but [...] the general tendency is that the greater the capital inflows from abroad, the lower the rate of growth of the receiving country" (Griffin and Enos, 1970, p. 318). A number of interacting reasons was listed for why aid may retard development, but particular attention was paid to the observation that aid leads to lower domestic savings. Rahman (1968) had already made this observation, which was confirmed by Weiskopf (1972).

Papanek acknowledged that the so-called "revisionist" contributions were useful in challenging overly optimistic views on the positive benefits of foreign inflows. Yet, he also pointed out that as long as the effect of an additional unit of foreign resources on investment is less than one, its effect on savings will appear to be negative. Newlyn (1973) elaborated on this and demonstrated that while negative values between 0 and -1 of regression parameters would normally mean a reduction in the dependent variable (in this case national resources used for investment to promote growth) no such implication can be drawn in the aid-savings context. Only if the negative parameter value exceeds unity can it be concluded that aid leads to an absolute reduction in the total amount of resources being used for investment. Newlyn argued that most writers had failed to make the above distinction.

The issues debated in the first generation of empirical work have continued into the 1990s. To understand this approach it is useful to lay out the underlying analytical framework. The core of the Harrod-Domar model is the Leontief production function and the assumption of excess supply of labour. No substitution among production inputs is possible, and output is linearly related to capital, i.e., the scarce factor of production. Capital accumulation is then the key to development. The only way in which savings, domestic and foreign (including aid), can impact on growth in this model is through the accumulation of physical capital, i.e., investment. Assuming the capital-output ratio, $v$, is constant, the growth rate in production, $g_{Y t}$, is given as

$$
g_{Y t}=\frac{\dot{Y}_{t}}{Y_{t}}=v \frac{\dot{K}_{t}}{Y_{t}},
$$

where $Y_{t}$ is production in year $t, K_{t}$ is the capital stock and a dot denotes changes over time. Relating changes in the capital stock to gross investment $I_{t}$ and allowing for a constant depreciation rate of capital, $\delta$, it follows that

$$
g_{Y t}=v \frac{I_{t}}{Y_{t}}-\delta=v i_{t}-\delta .
$$

In a closed economy, the investment ratio, $i_{t}$, can be replaced by the domestic savings ratio, $s_{t}$. However, in an open economy the relation between savings and investment is defined as

$$
I_{t} \equiv S_{t}+F_{t}=S_{t}+A_{t}+F_{p t}+F_{o t},
$$


where $F_{t}$ is the total inflow of foreign resources, including aid, $A_{t}$, as well as private and other foreign inflows, respectively $F_{p t}$ and $F_{o t}$. Expressing domestic savings, $S_{t}$, and foreign inflows as fractions of $Y_{t}$, the following identity appears:

$$
i_{t} \equiv s_{t}+a_{t}+f_{p t}+f_{o t}
$$

Assuming that $\partial f_{p t} / \partial a_{t}=\partial f_{o t} / \partial a_{t}=0$, i.e., aid has no impact on private and other foreign inflows, the marginal effect of aid on investment reduces to: ${ }^{4}$

$$
\frac{\partial i_{t}}{\partial a_{t}}=\frac{\partial s_{t}}{\partial a_{t}}+1 .
$$

From eq. (5) it is clear that the impact of aid on domestic savings has implications for how the macroeconomic effectiveness of aid is assessed, as the aid-savings link, in turn, affects the investment ratio.

Going back to the early empirical literature, the following simple equation was often used in analysing the aid-savings relation:

$$
s_{t}=\alpha_{0}+\alpha_{1} a_{t},
$$

where $\alpha_{0}$ is the marginal savings rate and $\alpha_{1}$ captures the impact of aid inflows (as a share of income) on the savings rate. ${ }^{5}$ Moreover, $f_{t}$ was regularly used as a proxy for $a_{t}$ due to lack of appropriate data on aid flows. Level variables (rather than ratios) were relied on in a few instances, with $Y_{t}$ explicitly included rather than implicitly present in the ratios. Eq. (6) is a crucial relationship in the aid-growth debate. For example, White (1992b), in his survey, argues that there is no agreement as to the positive or negative relationship between aid and savings and, with no empirical basis, suggests that the relationship may be positive. The sign and magnitude of the aid-savings parameter has as already alluded to been the focus of much empirical debate, rather than the amount of resources available for investment.

Turning now to our survey of the empirical literature, we first look at how aid affects savings (i.e., the first generation issue), and then move on to the different analytical model underlying second generation estimations (Section 3). Our survey is based on a comprehensive inventory, including 131 cross-country regressions, where aid is treated as

\footnotetext{
${ }^{4}$ This assumption is not always justified. Aid may interact with foreign private flows in both positive and negative ways. If increased aid is interpreted as a signal that greater political stability can be expected in the recipient country, private flows may increase. In contrast, if more aid is perceived as a signal that an economy is experiencing economic difficulties this may have a negative impact on other foreign inflows.

${ }^{5}$ This equation can be interpreted as a behavioural relation where the level of savings depends on the levels of income and aid, so $S_{t}=\alpha_{0} Y_{t}+\alpha_{1} A_{t}$. The marginal impacts of respectively income $\left(\alpha_{0}\right)$ and aid $\left(\alpha_{1}\right)$ are in the formulation implicit in eq. (6) allowed to differ. In case aid is perceived as a perfect substitute for other kinds of income (i.e., fully fungible), the two marginal effects on savings are equal.
} 
an exogenous variable, identified in the literature published from the late 1960s to $1998 .^{6}$ Studies in which aid is an endogenous variable are few, mostly of recent date, and merit special attention (Section 4).

In what follows, the three dependent variables include savings (S), investment (I), and growth $(\mathrm{G})$. Regarding the explanatory variables focus is naturally on aid inflows. However, in many of the early aid effectiveness studies aid flows are not identified separately from other foreign capital inflows. The 131 regression results are therefore classified in two groups. In the first group, with a total of 104 regressions, the explanatory variables include a clearly identified measure of aid (A), roughly equivalent to the DAC concept of official development assistance (ODA). The remaining 27 studies, in which aid cannot be separated from the various aggregate foreign inflow measures, were placed in a second group $(\mathrm{F})$. The number of regressions in which the impact of either A or F on respectively $\mathrm{S}$, I, and $\mathrm{G}$ is analysed adds up to respectively 41,18 , and 72 . We, finally, recorded the number of significantly positive, insignificant, and significantly negative relations between the dependent and the explanatory variables. ${ }^{7}$

This survey approach is subject to pitfalls. Some regressions are more meaningful than others, and it is possible that many authors made the same mistakes. Our categorical analysis, however, is consistent with Leamer's "extreme bounds analysis" (Leamer, 1985) and the variation thereof used recently by Sala-i-Martin (1997) in his analysis of the robustness of parameters in growth regressions. One important difference between the extreme bounds analysis and our exercise is that we are not in control of the experiments, i.e., the variations in explanatory variables and samples. In our view this adds power and credibility to the results. In any case, the categorical analysis is one way of structuring the sample of empirical aid effectiveness results without too much selectivity and value judgement, and we think this is a necessary first step in the search for general conclusions about what the literature can really tell.

In our sample of 41 aid-savings regressions there are analyses where more complex functional forms than eq. (6) are used, and systems of equations have also been relied on to estimate the impact of aid on savings. Different empirical specifications of the aidsavings relationship carry with them distinct implications concerning the underlying

\footnotetext{
${ }^{6}$ The 131 cross-country regressions surveyed in Sections 2 and 3 were identified from the 29 articles, papers and books listed in Appendix A. Most books and papers included in the survey contain more than one empirical estimation. As such, they represent several observations regarding the impact of aid on economic performance. A list of the 131 regressions and all details about their classification is available from the authors.

${ }^{7}$ The preparatory work behind the survey involved a series of cross-tabulations in which the 131 crosscountry regression observations were organised as a set of categorised data. The following classification scheme was used: Region, sample period, and analytical method. Ideally, it would have been desirable to study as well any impact arising from sub-sampling by income group. This was left for further research as information going beyond what is available in published sources would be required to reach solid conclusions.
} 
savings behaviour in the economy, and a justified critique of much of the empirical aidsavings work is that these behavioural implications have not generally been recognised and explored. ${ }^{8}$ Nevertheless, in trying to better understand the aid-savings debate, including the work of Griffin and Enos (1970), it is illustrative to summarise the available results as done in Table 1 (first row). Here the underlying null-hypothesis is $\alpha_{1}=0$. Thus, this summary of the aid-savings results follows the conventional path in which regressions have been presented and discussed in the literature, including the survey articles by Michalopoulos and Sukhatme (1989) and White (1992a).

Table 1: The Impact of Aid on Savings, Investment, and Growth in Cross-Country Regressions with Exogenous Aid ${ }^{9}$

\begin{tabular}{lcccc|cccc}
\hline $\begin{array}{l}\text { Exp. Variable } \\
\text { Dep. var. / Result }\end{array}$ & $(-)$ & 0 & $(+)$ & Total & $(-)$ & 0 & $(+)$ & Total \\
\hline Savings & 14 & 10 & 0 & 24 & 11 & 5 & 1 & 17 \\
Savings* & 1 & 13 & 8 & 22 & 0 & 7 & 10 & 17 \\
Investment & 0 & 1 & 15 & 16 & 0 & 0 & 2 & 2 \\
Growth & 1 & 25 & 38 & 64 & 0 & 6 & 2 & 8 \\
\hline
\end{tabular}

Note: The null hypotheses are tested $5 \%$ significance level against a two sided alternative.

* The null hypothesis in this row is $\alpha_{1}=-1$. Hence the (-), $0,(+)$ cells represent $\alpha_{1}<-1, \alpha_{1}=-1$, and $\alpha_{1}>$ -1 .

From Table 1, it is clear that there is only one study reporting an estimate of $\alpha_{1}$ which is significantly greater than zero. Hence, arguments suggesting that the impact of aid on domestic savings is positive are speculative. More than $60 \%$ of the observations in Table 1 (row 1) show a significant negative coefficient from aid to savings. This suggests that aid cannot be assumed to increase total savings on a one-to-one basis. In other words, there is plenty of empirical grounds on which to conclude that the early extreme pro-aid view on the macroeconomic impact of aid is not tenable.

This brings us to the other extreme of the debate where the negative parameter estimates in Table 1 (row 1) have been interpreted as a confirmation that aid is harmful to growth. In his counter-attack on this position, Papanek (1972) gave a number of reasons for expecting a negative link between aid and savings. The issue is not, however, whether the

\footnotetext{
${ }^{8}$ It may be useful to recall here that understanding the determinants of savings is not just a problem in developing countries. Browning and Lusardi (1996) argue from a microeconomic perspective that even though numerous empirical studies of savings and consumption have been carried out and published, the question "why people save" remains largely unanswered. A recent study by Masson, Bayoumi, and Samiei (1998) approaches the issue from a macroeconomic perspective and examines possible savings determinants using both time-series and cross-sectional data. Interesting results emerge, but heterogeneity is characteristic. ${ }^{9}$ Annex A includes an overview of the sources for the classification of the 131 regressions, whose main
conclusions are summarised in Table 1.
} 
coefficient is negative, but whether it is between 0 and -1 . Eq. (5) clearly shows that Papanek and Newlyn were right in arguing that a negative $\alpha_{1}$-parameter in the aid-savings relation in eq. (6) is consistent with a positive aid-impact on total investment as long as $\alpha_{1}$ $>-1 .{ }^{10}$ When $\alpha_{1}=-1$, aid has no impact on investment, and only when $\alpha_{1}<-1$ can it be concluded that the impact of aid on investment, and therefore growth, is harmful.

In assessing the investment implications of the aid-savings studies, which is what should ultimately concern us if we are interested in the growth impact of aid, it appears more reasonable to use as null hypothesis that $\alpha_{1}=-1$. Therefore, we derived the test statistics for this alternative hypothesis for 39 out of the 41 aid-savings analyses. As shown in Table 1 (row 2), the number of studies with an $\alpha_{1}$-estimate significantly less than -1 is limited to one observation. In contrast, there is a total of 18 analyses where the aid impact is significantly greater than -1 , leaving 20 regressions where $\alpha_{1}$ is not significantly different from -1 .

Robustness is an issue. Confidence bounds are in general very broad, partly reflecting the low number of observations in many of the first-generation studies. For example, there are six studies with no more than 10 degrees of freedom, and only four studies with more than 100 degrees of freedom. It is also evident that savings-investment behaviour is poorly captured in the studies surveyed. The end result is that the values -1 and 0 are inside the confidence bounds for $\alpha_{1}$ in the majority of cases.

Some sound conclusions do emerge from the first-generation studies. Neither extreme view of the aid-savings-growth link is valid. There is no evidence for a positive impact, and in only one study does aid lead to lower total savings. The overwhelming evidence from these studies is that aid leads to an increase in total savings, although not by as much as the aid flow. Given the underlying Harrod-Domar model, the implication is that aid spurs growth.

\section{Aid, Investment, and Growth: Second-Generation Studies}

The macroeconomic impact of aid on savings is an indirect way of trying to come to grips with the aid-growth relationship. In the second generation of empirical work, focus turned to estimating the link between aid and growth. Some estimated the link via investment and some directly in reduced form equations. In so far as there is an underlying structural model, focus remains on capital accumulation and is consistent with the Harrod-Domar model or a simple Solow neoclassical growth model.

Regardless of the choice of growth model, the view is that investment is the major direct determinant of growth. The implicit assumption in the 18 cross-country aid-investment studies in Table 1 is that, if a positive relationship can be found between aid and investment, it is justified to conclude that aid makes a positive contribution to growth. Moreover, while the specifications of the aid-investment relationship in the regressions

\footnotetext{
${ }^{10}$ If $S_{t}=\alpha_{0} Y_{t}+\alpha_{1} A_{t}$ and it is tentatively assumed that $Y_{t}=\beta_{0}+\beta_{1} A_{t}$, the implied investment effect is positive as long as $\alpha_{1}>-1-\alpha_{0} \beta_{1}$, which will normally be less than -1 .
} 
included in our sample vary, their core typically includes a behavioural equation linking investment to aid.

Papanek argued that focus in the aid-effectiveness debate should shift away from the aidsavings relationship to examining the effects of aid on the various elements of investment and growth. Accordingly, he proposed a model in which the different financing components of investment - domestic savings, aid, and other foreign capital inflows - are separated. This advice was followed in subsequent aid-investment studies, where the assumed investment behaviour can generally be expressed as follows: ${ }^{11}$

$$
i_{t}=h\left(s_{t}, a_{t}, f_{p t}, f_{o t}\right) .
$$

In the overwhelming number of studies, analyses of the aid-investment link are based on results where $\mathrm{A}$, rather than $\mathrm{F}$, is explicitly included among the explanatory variables (Table 1, row 3). This is in contrast with the aid-savings regressions, and reflects in part that second-generation aid-investment studies generally consider domestic as well as foreign sources of capital accumulation as separate explanatory variables in a behavioural equation.

A typical linear regression form derived from eq. (7) is given by a reduced form equation:

$$
i_{t}=\gamma_{0}+\gamma_{1} s_{t}+\gamma_{2} a_{t}+\gamma_{3} f_{p t}+\gamma_{4} f_{o t}
$$

where the parameters are

$$
\gamma_{1}=\frac{\partial i}{\partial s} ; \quad \gamma_{2}=\frac{\partial i}{\partial a} ; \gamma_{3}=\frac{\partial i}{\partial f_{p}} ; \quad \gamma_{4}=\frac{\partial i}{\partial f_{o}}
$$

We return to eq. (9) below, as the widespread use of this behavioural specification has critical implications for how empirical aid-growth results are interpreted. In the studies in Table 1 (row 3 ) there is virtual consensus that there is a significant positive impact of aid on investment, (the parameter $\gamma_{2}$ ). Only one study, based on a very early pre-1970 sample period (Massell, Pearson and Fitch, 1972), found an insignificant coefficient. All other studies have a significantly positive parameter. In sum, it is safe to assert that the investment enhancing effect of aid is clear. The link to growth is a separate step.

A second strand of the second-generation literature explores the link between aid and growth in reduced form equations. Over the past 30 years no less than 72 cross-country studies have tested whether or not a direct impact of aid on growth can be identified. Some of these regressions have taken a growth equation similar to eq. (2) as their point of departure, but in most cases the investment ratio $i_{t}$ has been substituted by a behavioural specification such as the one in eq. (8). Accordingly, the typical second-generation aid-

\footnotetext{
${ }^{11}$ Note that while eq. (4) is an accounting identity, eq. (7) is a behavioural equation in line with the assumptions in the literature surveyed here.
} 
growth regression is

$$
g_{Y t}=\lambda_{0}+\lambda_{1} s_{t}+\lambda_{2} a_{t}+\lambda_{3} f_{p t}+\lambda_{4} f_{o t},
$$

where $\lambda_{0}=v \gamma_{0}-\delta$, and $\lambda_{\mathrm{i}}=v \gamma_{\mathrm{i}},(i=1, \ldots 4)$.

This reduced form equation is consistent with a variety of alternative structural models. While the original derivation of the Papanek regression was based on the Harrod-Domar growth model, this regression is also applicable when the underlying model is of the Solow type where substitution among production inputs is allowed. In this case the auxiliary assumptions are that the growth rates in the labour force and technology and, especially, the capital-output ratio are constant over time. These assumptions hold in steady state, and in the small open economy model by Barro et al. (1995) in which the user cost of physical capital is constant and given from abroad. To the extent that underlying assumptions do not hold, standard deviations on parameter estimates should increase even though the parameter estimates may still be unbiased. In empirical work, this implies a relatively higher share of insignificant estimates.

If it is assumed that $\gamma_{i}$ equals unity, the corresponding $\lambda_{i}$ parameter estimates in eq. (10) should all equal the capital-output ratio, $v$. However, interpreting (8) as a reduced form, allowing for a behavioural relationship between gross investment, on the one side, and savings, aid, and foreign inflows, on the other, leads to partial derivatives that may be different from unity. This implies that the regression coefficients may differ both from each other and from $v$.

In assessing aid effectiveness from the reduced form regression, the parameter of immediate interest is $\lambda_{2}$. An insignificant estimate of this parameter has in many studies led to the conclusion that aid does not affect growth. However, this statement involves a composite hypothesis: (i) $v \neq 0$ and (ii) $\gamma_{2}=0$. Not only the latter assumption regarding the marginal effect of aid on investment, but also the underlying model specification, impacts on the conclusions drawn about aid effectiveness. Yet, neither $v$ nor $\gamma_{2}$ can be identified from the regression parameters without an additional, auxiliary assumption. A natural choice is that $\gamma_{1} \neq 0$. This is equivalent to assuming that domestic savings have a positive impact on investment and growth whenever $v>0$, and a minimum requirement to conclude that aid has no impact on growth in the reduced form regression is that $\hat{\lambda_{1}} \neq 0$ while $\hat{\lambda_{2}}=0$.

As shown in Table 1 (row 4), there is only one result in our survey that indicates a directly harmful effect of aid on growth. On the other hand, among the remaining 71 analyses, 40 show a positive impact of aid on growth, while 31 show no statistically significant impact. At first sight the evidence may appear mixed. A review of the 31 insignificant results reveals, however, that no less than 12 of these are based on regressions, which do not fulfill the minimum requirement for concluding that aid has no impact on growth (Table 2). When the aid coefficient is insignificant, so is the savings coefficient. 
Table 2: Aid-Effectiveness Results from Papanek Regressions

\begin{tabular}{lcccc}
\hline Study & $\begin{array}{l}\lambda_{1} \neq 0 \\
\lambda_{2} \neq 0\end{array}$ & $\begin{array}{l}\lambda_{1} \neq 0 \\
\lambda_{2}=0\end{array}$ & $\begin{array}{l}\lambda_{1}=0 \\
\lambda_{2}=0\end{array}$ & $\begin{array}{l}\lambda_{1}=0 \\
\lambda_{2} \neq 0\end{array}$ \\
\hline Papanek (1973) & 4 & 1 & & 1 \\
Stoneman (1975) & 9 & & 1 & 1 \\
Dowling and Heimenz (1982) & 1 & 2 & 1 & \\
Gupta and Islam (1983) & 3 & 1 & 1 & 1 \\
Singh (1985) & 1 & 3 & 6 & 2 \\
Mosley et al. (1987) & 1 & & 3 & 1 \\
Mosley et al. (1992) & 1 & 1 & & 1 \\
White (1992a) & 2 & 1 & & 12 \\
Snyder (1993) & 1 & 9 & & 1 \\
\hline Total & 23 & & & \\
\hline
\end{tabular}

Note: From Tables 1 and 2 it follows that out of the 72 aid-growth regressions analysed here, 51 had a functional form which can be characterised as a Papanek regression. It also follows that there are 10 insignificant results among the remaining 21 non-Papanek regressions.

Some of the most widely cited results about aid-effectiveness are those by Mosley, Hudson, and Horrell $(1987,1992)$. In these analyses and several others, it is concluded that aid does not seem to spur growth, giving rise to the suspicion that there is a micro-macro paradox to be explained. In fact, in the large majority of their regressions, the savings coefficient is insignificant. Rather than emphasizing that aid does not work, the real puzzle in their results is that savings do not work. This result raises the question whether the underlying structural model is appropriate in their particular analysis.

Out of the 32 regressions where the identifying assumption is fulfilled (i.e., $\lambda_{1} \neq 0$ ), there are 23 significant and only nine insignificant results (including three from the studies by Mosley et al.). The number of studies that find a significant link between aid and growth is impressive, especially given the simplicity of the reduced form equation and the quality of data relied on; and the reduced form Papanek-type regressions that found a significant aid-growth link are in general based on more observations than those that found insignificant links.

A review of the 21 aid-growth reduced form regressions in our sample that have been classified as not relying on the Papanek approach shows that all of the ten insignificant results are from either very early and/or simple (correlation) regressions with few degrees of freedom or in studies where total foreign capital inflows rather than aid is being studied (Griffin and Enos, 1970; Massell et al., 1972; Voivodas, 1973; Bornschier et al., 1978; Mosley, Hudson, and Horrell, 1987). Recent analyses with a reasonable number of degrees of freedom report positive and significant results. 
To summarise, we can draw a number of clear conclusions from second-generation studies. The aid-investment link is positive, consistent with the typical result from first-generation aid-savings studies. Moreover, the results from reduced form, aid-growth regressions suggest in a coherent way that there is a positive link between aid and growth whenever there is a positive link between savings and growth. This reduced form model is consistent with the aid-savings-investment-growth causal chain in standard growth models.

\section{Aid, Policy, and Growth: Third-Generation Studies}

Over the past few years, a new, third generation of aid-effectiveness studies has appeared. Compared to earlier work they break novel ground in four areas. First, they work with panel data for a number of years and a large number of countries. The data cover a large share of developing country trade and other economic activity. Second, new growth theory has inspired the analysis in distinct ways, providing a different analytical basis compared to previous work. Measures of economic policy and the institutional environment are included directly in the reduced form growth regressions alongside traditional macroeconomic variables. Third, endogeneity of aid and other variables is addressed explicitly in some studies. Finally, the aid-growth relationship is explicitly seen as non-linear. While some of the earlier analyses addressed some of these issues, in our view, the third-generation studies represent a distinct step forward in empirical cross-country work on aid effectiveness. ${ }^{12}$

The studies by Boone (1996) and Burnside and Dollar (1997) have attracted particular attention in the public, and they have both been reviewed and discussed extensively in a number of papers, including for example Feyzioglu et al. (1998), McGillivray and Morrissey (1998), and Tsikata (1998). The Boone study must be characterised as an outlier in the literature. While inspired by modern economic theory, it is, based on the empirical estimations, concluded that aid has no effect on investment and growth. This result Tsikata (1998) finds surprising, and it is indeed a result that is completely at odds with the broad range of investment studies we have surveyed in Section 3, including in particular the excellent, up-to-date analysis by Feyzioglu et al. (1998). Careful reading of Boone's work also shows that he decides, in passing, to discard the result that aid does have an impact on investment when his full sample is used. Finally, while Boone endogenises aid, his results are subject to queries such as why he has not endogenised the growth rate of income per capita. For these reasons, and to keep the exposition manageable, we focus in what follows on Burnside and Dollar (1997) and three other recent aid-effectiveness studies: Hadjimichael et al. (1995), Durbarry et al. (1998), and Hansen and Tarp (1999). Together these four contributions represent the present core of the new third-generation empirical analyses of aid-effectiveness.

\subsection{Overview}

The four third-generation studies in focus here share a common theoretical background, and

\footnotetext{
12 Note that Mosley (1980) is a forerunner when it comes to recognising the endogeneity of aid in empirical testing. Yet, while trying to address this problem at an early stage, he treated savings as exogenous.
} 
even if the specific formulation of the growth relations and the choice of econometric technique differ, they have indeed a lot in common from an analytical perspective. We briefly summarise these contributions below, highlighting differences, rather than similarities. Table 3 gives an overview of some of the parameters included in the estimated growth relations. The dependant variable is in all cases the average annual growth rate of real per capita GDP.

The main scope of the study by Hadjimichael et al. (1995) is to investigate the impact of macroeconomic policies, exogenous factors, and structural reforms on growth, savings, and investment in Sub-Saharan Africa. This, and insights gained from empirical growth analysis of the determinants of growth, savings, and investment over the past decade, lead the authors to include the following specific policy variables in the regressions: government investment, the public budget deficit, and inflation. In addition to government investment, private investment is included as well and, as a novelty compared to earlier-generation work, a squared aid term is present to capture possible non-linearities in the aid-growth relations. The results in Table 3 (column 1) are based on a regression analysis for the period 1987-92 with 31 Sub-Saharan African countries in the sample. Some 186 observations are available, and the panel data structure is utilised in two ways. There is, first, an intercept for each year in the sample. These intercepts are included to capture the effect of shocks that are common to all of the countries in each of the years, but not captured by other included variables (i.e., the world business cycle). Second, Hadjimichael et al. use weighted least squares to account for country-wise heteroscedasticity, and they attempt to address the potential endogeneity of aid and economic policy by lagging most of the explanatory variables, including foreign aid, one year. The main policy conclusion drawn is that the poor economic performance of Sub-Saharan Africa stems from differences in economic policies, but the positive growth impact of aid is also recognised.

Turning next to Durbarry et al. (1998) (Table 3, column 2), they use a Papanek-inspired decomposition of investment as in eq. (4), but they allow for possible non-linear effects of aid on growth by including a squared aid term. This reduced form specification is not strictly in accordance with the Papanek investment specification but, referring to Hadjimichael et al., Durbarry et al. argue that the possibility of non-linearity in the aidgrowth relationship should be recognised from the outset. The main differences between these two studies relate to data coverage and estimation technique. Durbarry et al. analyse 58 developing countries over the period 1970-93. Annual data are used to construct four periods (averages over six years) and 238 observations. The results presented in Table 3 are from a mixed estimation procedure in which the time dimension is modelled using different intercepts in each period, while the cross-country dimension is modelled using a random error term. ${ }^{13}$ The main conclusion is that there is robust evidence that greater foreign aid inflows have a beneficial impact on growth. The existence of an optimal aid allocation in terms of growth effects is also identified.

${ }^{13}$ Endogeneity of aid is not dealt with in the study. 
Table 3: A Comparison of Recent Growth Regressions

\begin{tabular}{|c|c|c|c|c|}
\hline & $\begin{array}{c}\text { Hadjimichael et al. } \\
\text { (1995) }\end{array}$ & $\begin{array}{c}\text { Durbarry et al. } \\
(1998)\end{array}$ & $\begin{array}{c}\text { Burnside \& } \\
\text { Dollar (1997) } \\
\end{array}$ & $\begin{array}{c}\text { Hansen \& Tarp } \\
(1999)\end{array}$ \\
\hline Aid & $\begin{array}{c}0.098 * * \\
(2.22)\end{array}$ & $\begin{array}{c}0.101 * * \\
(2.26)\end{array}$ & $\begin{array}{l}-0.58 \\
(1.23)\end{array}$ & $\begin{array}{c}0.938 * * \\
(3.94)\end{array}$ \\
\hline $\mathrm{Aid}^{2}$ & $\begin{array}{c}-0.002 * * \\
(2.57)\end{array}$ & $\begin{array}{c}-0.001 * * \\
(2.01)\end{array}$ & & $\begin{array}{c}-1.870 * * \\
(4.61)\end{array}$ \\
\hline Aid x Policy & & & $\begin{array}{l}0.32^{*} \\
(1.78)\end{array}$ & \\
\hline Private inv. & $\begin{array}{l}0.014 \\
(0.53)\end{array}$ & & & \\
\hline Government inv. & $\begin{array}{c}0.178 * * \\
(3.43)\end{array}$ & & & \\
\hline Domestic Saving & & $\begin{array}{c}0.064 * * \\
(3.17)\end{array}$ & & \\
\hline Private net inflows & & $\begin{array}{c}0.237 * * \\
(3.80)\end{array}$ & & \\
\hline Other inflows & & $\begin{array}{l}0.006 \\
(0.83)\end{array}$ & & \\
\hline Human capital & $\begin{array}{c}0.161 * * \\
(3.36)\end{array}$ & & & \\
\hline Population growth rate & $\begin{array}{c}-0.890 * * \\
(2.54)\end{array}$ & & & \\
\hline Terms of trade & $\begin{array}{c}0.029 * * \\
(1.99)\end{array}$ & $\begin{array}{c}0.090 * * \\
(3.29)\end{array}$ & & \\
\hline Real effective exchange rate & $\begin{array}{c}-0.045^{* *} \\
(2.94)\end{array}$ & & & \\
\hline Openness & & & $\begin{array}{l}1.46 * * \\
(2.06)\end{array}$ & $\begin{array}{c}0.027 * * \\
(4.94)\end{array}$ \\
\hline Inflation & $\begin{array}{c}-0.034^{*} \\
(1.94)\end{array}$ & $\begin{array}{c}-0.001 * * \\
(3.20)\end{array}$ & $\begin{array}{c}-1.16^{* *} \\
(2.09)\end{array}$ & $\begin{array}{c}-0.011 * * \\
(2.55)\end{array}$ \\
\hline Budget deficit & $\begin{array}{c}-0.168 * * \\
(4.61)\end{array}$ & $\begin{array}{c}-0.066^{* * *} \\
(2.00)\end{array}$ & $\begin{array}{l}-0.08 \\
(0.01)\end{array}$ & \\
\hline Government consumption & & & $\begin{array}{l}-2.59 \\
(0.30)\end{array}$ & $\begin{array}{c}-0.289 * * \\
(2.88)\end{array}$ \\
\hline Financial depth & & $\begin{array}{l}0.007 \\
(0.73)\end{array}$ & $\begin{array}{l}0.019 \\
(1.14)\end{array}$ & $\begin{array}{c}-0.073 * * \\
(2.07)\end{array}$ \\
\hline Institutional quality & & & $\begin{array}{l}0.69 * * \\
(3.70)\end{array}$ & -- \\
\hline Initial GDP per capita & & & $\begin{array}{l}-0.95 \\
(1.11) \\
\end{array}$ & $\begin{array}{c}-0.056^{* *} \\
(2.62) \\
\end{array}$ \\
\hline Sample period & $1987-92$ & $1970-93$ & $1970-93$ & 1974-93 \\
\hline Countries/Periods & $31 / 6$ & $58 / 4$ & $56 / 6$ & $56 / 5$ \\
\hline Observations & 186 & 238 & 267 & 264 \\
\hline $\mathrm{R}^{2}$ & 0.4 & 0.32 & 0.38 & 0.53 \\
\hline
\end{tabular}

Note: Due to differences in the measurement of aid and growth (fractions/percentages) the parameter estimates are not directly comparable across the table. However, the effect of aid is directly comparable for the first two and the last two columns, respectively.

Source: Hadjimichael et al. (1995, Table 25), Durbarry et al. (1998, Table 3), Burnside and Dollar (1997, Table 3), and Hansen and Tarp (1999, Table 7). 
Burnside and Dollar (1997) (Table 3, column 3) draw, as is the case with Hadjimichael et al., on the latest empirical results in the new growth literature. In addition to economic policy variables, they include several institutional and political variables that have appeared in growth studies in the mid-nineties (e.g., assassinations, ethnic fractionalization, and institutional quality). Furthermore, conditional convergence effects are captured by including the initial level of real GDP per capita. However, the major novelty in the Burnside and Dollar study - and the hottest issue in the debate - is the inclusion of an interaction term between foreign aid and economic policies. This specification is, as further discussed below, another way of capturing non-linearity in the aid-growth relationship than the introduction of a squared aid term in the Hadjimichael et al. and Durberry et al. studies. Economic policies are grouped in a single policy index consisting of a composite measure of inflation, trade openness, and the budget deficit. The interpretation of the aid-policy interaction term is that the effectiveness of aid in the growth process is directly dependent on the quality of economic policies. The results presented in Table 3 are based on data for 56 countries and 267 observations. The time dimension involves six periods based on fouryear averages covering the period 1970-93. Endogeneity of aid is taken into account by using a instrumental variable procedure, while endogeneity of the policy variables is tested and rejected. As in the studies by Hadjimichael et al. and Durbarry et al., the panel data structure is used to remove the world business cycle by including different intercepts in each of the six periods. ${ }^{14}$ The main conclusion relates to the statistical significance of the aid-policy interaction term, which is used to argue that aid has a positive impact on growth in a good policy environment.

The last column in Table 3 presents results from the study by Hansen and Tarp (1999). They analyse the same set of countries as Burnside and Dollar and they use the same basic model formulation. The sample of 264 observations covers 56 countries over five periods for 1973-93. In addition, Hansen and Tarp take account of unobserved country-specific effects, conditional convergence, and endogeneity of aid and policies by using an estimation technique for dynamic panel data models with country specific effects. They model the non-linear effect of aid by including a squared term as done by Hadjimichael et al. and Durbarry et al. Both aid and aid squared are significantly affecting the growth rate, and the same goes for all of the various policy variables.

The main results in comparative perspective are, as can seen from Table 3, that Hadjimichael et al., Durbarry et al., and Hansen and Tarp all find a significant impact of aid on growth, as long as the aid to GDP ratio is not excessively high. ${ }^{15}$ In contrast,

\footnotetext{
${ }^{14}$ Another difference between the Burnside and Dollar study and the other three studies is that Burnside and Dollar use a new measure of aid flows (Effective Development Aid, EDA), see Chang et al. (1998). However, in the World Bank (1998) study it is stated that the choice between the standard aid measure (ODA) and the new measure (EDA) makes no significant difference in estimations.

15 In Hadjimichael et al. and Hansen and Tarp the turning point from which increased aid will have a negative effect on growth is an aid/GDP ratio of about 25 percent. In Durbarry et al. this ratio is about 40 percent. However, as argued below, the empirical identification of a turning point should be interpreted with
} 
Burnside and Dollar find that the effectiveness of aid depends on economic policy. They conclude that aid has a positive impact on growth, but only in a good policy environment. Given the differences in samples and estimation techniques, the results in terms of the effectiveness of aid are strikingly similar in the three studies by Hadjimichael et al., Durbarry et al. and Hansen and Tarp. Finally, it is evidently of great policy relevance to sort out the reason for the apparent difference between the Burnside and Dollar study, on the one hand, and the three other studies, on the other, when it comes to the treatment of nonlinearities in the aid-growth relation. We address this question below.

\subsection{Analytical Framework}

There are several reasons for expecting a non-linear relation between aid and growth. Hadjimichael et al. argue that many Sub-Saharan African countries may have limited capacity to absorb foreign resources. ${ }^{16}$ Likewise, Durbarry et al. refer to absorptive capacity and they add more recent results about optimal borrowing and Dutch disease problems. The analysis of absorptive capacity constraints is based on the Harrod-Domar and two-gap growth models. If the Leontief production function in this framework is replaced by a Cobb-Douglas production function, as in the Solow growth model, there is no longer a fixed capacity constraint (a threshold) but, instead, diminishing marginal returns to increased foreign aid. The decreasing marginal returns can in empirical work be approximated by a second order polynomial in aid by including aid and aid squared in the regression. In general, however, quadratic terms and interactions must be evaluated and interpreted with great care in regression models. They represent separate terms in a second order approximation of what is really an unknown functional form.

A simple example that clarifies the role of squared terms and interactions is a linearisation of a Solow growth model with constant growth rates in population and technology, and a constant rate of depreciation. Assuming investments are partly from domestic savings and partly from foreign aid, the model can be formulated in several ways, with observationally equivalent first order approximations and second order approximations that (observationally) differ only with respect to the interaction term.

In a standard Solow model with convergence effects, growth in income per worker can be expressed as a log-linear relation, following Mankiw, Romer and Weil (1992):

$$
g_{y t}=\alpha_{0}+\alpha_{1} \log \left(i_{t}\right)-\rho \log \left(y_{0}\right)
$$

where the last term is included to capture initial deviations from steady state.

great care.

16 This argument can be based on the analysis of absorptive capacity constraints by Chenery and Strout (1966) and later followers. 
Investments can be modelled as in Section 2.2 (assuming private foreign flows are zero)

$$
i_{t}=\gamma_{1} s_{t}+\gamma_{2} a_{t}
$$

Inserting savings and aid in the growth equation and linearising, using a first-order Taylor approximation, we obtain a familiar aid-growth relation: ${ }^{17}$

$$
g_{y t}=\tilde{\alpha}_{0}+\frac{\alpha_{1} \gamma_{1}}{\bar{\imath}} s_{t}+\frac{\alpha_{1} \gamma_{2}}{\bar{\imath}} a_{t}-\rho \log \left(y_{0}\right)
$$

where $\bar{\imath}=\gamma_{1} \bar{s}+\gamma_{2} \bar{a}$, in essence the sample mean, is used as the point of expansion. The linear relationship has typically been estimated using either least squares or instrumental variable estimators. ${ }^{18}$

A more precise, second-order Taylor approximation of the theoretical growth equation leads to an empirical reduced form where quadratic terms as well as an interaction term (e.g., a cross product) are present:

$$
g_{y t}=\hat{\alpha}_{0}+2 \frac{\alpha_{1} \gamma_{1}}{\bar{\imath}} s_{t}+2 \frac{\alpha_{1} \gamma_{2}}{\bar{\imath}} a_{t}-\frac{1}{2} \frac{\alpha_{1} \gamma_{1}^{2}}{\bar{\imath}^{2}} s_{t}^{2}-\frac{1}{2} \frac{\alpha_{1} \gamma_{2}^{2}}{\bar{\imath}^{2}} a_{t}^{2}-\frac{\alpha_{1} \gamma_{1} \gamma_{2}}{\overline{\mathrm{l}}^{2}} s_{t} a_{t}-\rho \log \left(y_{0}\right) .
$$

If savings and aid are assumed to provide different kinds of capital, the growth equation can be formulated as a log-linear in each of the investment components. In this case no interaction term appears in the second order Taylor approximation, only squared savings and aid terms.

In the studies by Hadjimichael et al., Burnside and Dollar, and Hansen and Tarp, the savings rate does not enter directly in the regressions. However, savings can be substituted out either by government and private investments, as in Hadjimichael et al., or by policy and institutional variables, as in Burnside-Dollar and Hansen-Tarp. In such cases, the nonlinear terms in eq. (14) will include squared policy and aid terms, and, depending on the growth specification, an interaction between aid and policy as well.

As can be seen from Table 3 all the recent studies include either aid squared or the policyaid interaction term from the second order expansions, yielding better approximations to

\footnotetext{
${ }^{17}$ Linearising converts the theoretical growth specification into an empirically manageable reduced form equation.

18 This example illustrates a possible reason why so many studies have found large differences in aid effectiveness for low- and middle-income developing countries. If the average investment rate, $\bar{\imath}$, around which the Taylor expansion is carried out, is correlated with the income level, the regression parameters in eq. (13) will be sample dependent.
} 
the underlying theoretical growth relation. Yet, none of the four studies include all second order terms. Further analysis is therefore required to understand the relative importance of the second order terms. Such insights are essential in arriving at an appropriate approximation to the underlying theoretical model.

The question at issue between the Burnside-Dollar study and the other three is which combination of non-linear terms is statistically preferred. In any empirical model interaction terms and squared terms may enter as "proxies" for each other, unless all terms are included initially. This rather unfortunate effect can be illustrated as follows:

A stochastic variable such as the policy index used by Burnside-Dollar can always be decomposed into two terms; one which is perfectly correlated with aid, and another which is completely uncorrelated with aid:

$$
\text { policy }=\text { אaid }+(\text { policy|aid })
$$

$\kappa$ is simply a regression coefficient, i.e., the sample covariance between the policy index and aid divided by the sample variance of aid. The "residual" (policy|aid) is the part of the policy index, which is uncorrelated with aid. Using this relation, the interaction term between aid and policy can be reformulated as:

$$
\text { aid } \times \text { policy }=\kappa^{2} \text { aid }^{2}+\text { aid } \times(\text { policy|aid }) .
$$

This demonstrates that the interaction term may be significant in regressions even though it may well be that it is the aid squared non-linearity in the aid-growth relation that is in reality important. Reversing the argument (aid as a "function" of policy) shows the other possibility; that aid squared is significant because of the importance of the aid-policy interaction. It is therefore very important in comparing and assessing the results of the four studies in focus here to test whether any of these two possibilities has empirical support.

\subsection{Testing Second Order Terms}

Table 4 presents results of re-estimations of the growth relation in which all three terms from the second order approximation in aid and policy are included. The regressions reported in Table 4 are based on the same sample used in Hansen-Tarp (1999). The data in this sample differ slightly from the Burnside-Dollar data. ${ }^{19}$

\footnotetext{
${ }^{19}$ We were unable to obtain all of the Burnside-Dollar data, although they kindly provided some. We filled in gaps based on other published sources. Our data set is very close to theirs, although we were unable to replicate their regressions exactly. Our data set is available on request.
} 
Table 4: Growth Regressions with Polynomial Effects of Aid and Policy

\begin{tabular}{|c|c|c|c|c|c|}
\hline \multicolumn{6}{|c|}{$\begin{array}{l}\text { Dependent variable: Growth rate of GDP per capita } \\
\text { Sample period: } 1974-93 \text {, Countries: } 56 \text {, Periods: } 5\end{array}$} \\
\hline Regression & 1 & 2 & 3 & 4 & 5 \\
\hline \multirow[t]{2}{*}{ Aid } & -0.018 & 0.03 & $0.166^{* *}$ & $0.165^{* *}$ & $0.182 * *$ \\
\hline & $(0.40)$ & $(0.88)$ & $(2.00)$ & (2.09) & $(2.21)$ \\
\hline \multirow[t]{2}{*}{ Aid x Policy } & $0.085 * *$ & -0.004 & -0.004 & & \\
\hline & $(2.60)$ & $(0.22)$ & $(0.24)$ & & \\
\hline \multirow[t]{2}{*}{$\mathrm{Aid}^{2}$} & & & $-0.003^{* *}$ & $-0.004 * *$ & $-0.004 * *$ \\
\hline & & & $(2.22)$ & $(2.32)$ & $(2.26)$ \\
\hline \multirow[t]{2}{*}{ Policy $^{2}$} & & & 0.082 & & \\
\hline & & & $(0.83)$ & & \\
\hline \multirow[t]{2}{*}{ Openness } & $1.498 * *$ & $2.193 * *$ & 1.466 & $2.07 * *$ & $2.13 * *$ \\
\hline & $(2.60)$ & (4.13) & $(1.47)$ & $(4.03)$ & $(4.07)$ \\
\hline \multirow[t]{2}{*}{ Inflation } & -0.798 & $-1.323 * *$ & $-1.338 * *$ & $-1.217 * *$ & $-0.979 *$ \\
\hline & $(1.44)$ & $(2.91)$ & $(2.80)$ & $(2.71)$ & $(1.83)$ \\
\hline \multirow[t]{2}{*}{ Budget deficit } & 4.59 & 7.339 & 7.415 & $7.73 *$ & $8.70 *$ \\
\hline & $(0.93)$ & $(1.59)$ & (1.58) & (1.93) & (1.91) \\
\hline \multirow[t]{2}{*}{ Government cons. } & -0.488 & -2.095 & -3.832 & -3.014 & -1.439 \\
\hline & $(0.10)$ & $(0.44)$ & $(0.80)$ & $(0.65)$ & $(0.29)$ \\
\hline \multirow[t]{2}{*}{ Financial depth } & 0.009 & 0.016 & 0.014 & 0.013 & 0.008 \\
\hline & $(0.67)$ & $(1.22)$ & (1.03) & $(1.01)$ & $(0.62)$ \\
\hline \multirow[t]{2}{*}{ Institutional quality } & $0.73 * *$ & $0.614 * *$ & $0.675 * *$ & $0.677 * *$ & $0.718 * *$ \\
\hline & $(4.24)$ & $(3.65)$ & $(3.96)$ & $(3.97)$ & $(4.11)$ \\
\hline \multirow[t]{2}{*}{ Initial GDP per capita } & -0.312 & -0.302 & -0.136 & -0.137 & -0.146 \\
\hline & $(0.54)$ & $(0.54)$ & $(0.24)$ & $(0.24)$ & $(0.25)$ \\
\hline Obs. & 238 & 243 & 243 & 243 & 238 \\
\hline $\mathrm{R}^{2}$ & 0.38 & 0.38 & 0.39 & 0.39 & 0.38 \\
\hline
\end{tabular}

Note: A constant and time dummies are included in all regressions. Regressions 1 and 5 exclude five observations in accordance with the analysis in Burnside and Dollar (1997). The five observations are: Nicaragua (1986-89, 1990-93), Gambia (1986-89, 1990-93), and Guyana (1990-93). The $t$-statistics in parantheses are based on heteroskedasticity consistent standard errors. **, and * indicate significance at 5 and $10 \%$, respectively.

Regressions 1 and 2 are identical in form and represent the Burnside-Dollar growth equation. In regression 1 we have excluded five outliers identified by Burnside and Dollar. ${ }^{20}$ When the outliers are excluded, there is a significant effect on growth from the aid-policy interaction term as found in the Burnside-Dollar study. However, it is distressing to note how sensitive the results for the aid and aid-policy interaction terms are. Once the five Burnside-Dollar outliers are included in the sample, the interaction term becomes insignificant. $^{21}$

Regressions 3 and 4, make use of the full data set and based on the results in regression 3

\footnotetext{
${ }^{20}$ They are: Nicaragua (1986-89, 1990-93), Gambia (1986-89, 1990-93), and Guyana (1990-93).

${ }^{21}$ To this end it should be noted that the five observations cannot be identified as outliers in regression 2. All regressions in Table 4 have the same extreme residual observations. Only three residuals are outside a three standard error band, while ten residuals are outside a two standard error band. The five observations excluded by Burnside and Dollar are not in any of these sets.
} 
we can evaluate the significance of the various aid and aid-policy interaction terms. Neither the squared policy nor the interaction term are statistically significant. In contrast, aid squared is statistically significant at a 5\% level of significance, with or without the other terms.

As a simple test of robustness of the result we have excluded the five influential observations in regression 5. As seen, by comparing regressions 4 and 5, these observations have no effect on the estimated parameters once aid squared is included. We take this as additional evidence in favour of modelling the non-linear relation between aid and growth using a second order polynomial in aid.

Finally, to check the sensitivity of the results for endogeneity of aid, we have replicated the regressions in Table 4 using instrumental variable (IV) estimation. As shown in Appendix B using IV estimation does not change any of the conclusions.

\subsection{Summing up}

The few third-generation studies draw on new growth theory, and work with reduced form equations that go well beyond standard first and second-generation analyses based on Harrod-Domar and simple neoclassical growth models. In the aid-growth literature these empirical studies introduce aid and aid-policy interaction terms to new growth theory regressions. Consistent with results from second-generation models, there is a significant effect on growth, either alone or in combination with a policy variable. Non-linear effects are significant both statistically and empirically. The result that there is a link between aid and growth is robust and consistent with past studies. The Burnside-Dollar result that there is a significant interaction between aid and policy is delicate. The other studies find a significant non-linear relationship through squared terms which is robust and dominates the aid-policy interaction effect when the two types of effects are considered together.

\section{Conclusions}

What can we conclude from this survey of cross-country literature on a long and contentious debate on the macroeconomic effectiveness of foreign aid. Other literature surveys hold, in the words of the Economist (26 June 1999), that "countless studies have failed to find a link between aid and faster growth". We have surveyed three generations of empirical work: early Harrod-Domar models, reduced form aid-growth model, and new growth theory reduced form models. We find a consistent pattern of results. Aid increases aggregate savings; aid increases investment; and there is a positive relationship between aid and growth in reduced form models. The positive aid-growth link is a robust result from all three generations of work. As a corollary, using perceived ineffectiveness of aid as an argument against cross-country regressions at large is not substantiated. Important information is, as shown in our work, embedded in the similarities among countries, and cross-country work does provide clues to how aid interacts with savings, investment, and growth. 
The obvious question is why do other surveys find that the aid-savings evidence is mixed and that the evidence in favour of a positive aid-growth link is weak - or non-existent? A few highly influential studies in each generation of work have argued the negative. There has been a tendency for negative studies to dominate the debate. Our survey covers 131 first and second generation regressions, available in the literature, and compares them, and third-generation work, in a common analytical framework. We find that in each generation of studies those arguing the negative are clearly in the minority. When all the studies are carefully considered as a group, the positive evidence is convincing. The micro-macro paradox is non-existent. Microeconomic studies indicating that aid is beneficial are consistent with the macroeconomic evidence.

Third-generation work goes beyond earlier empirical studies to address the necessary conditions for (increased) aid effectiveness. Burnside and Dollar (1997) offer a solution to what has so far appeared as a Gordian knot, i.e., the perceived ineffectiveness of aid at macro level, by arguing that aid is effective, but only in a good policy environment. This intriguing result, which is broadly in line with Washington consensus view of development, is appealing to many. It suggests how donors and aid-recipients can learn from mistakes in the past and improve aid-effectiveness in the future in a straightforward manner. This simple message is very influential and has even made it to the pages of the Economist.

Nevertheless, the basic Burnside-Dollar result turns out to be sensitive to data and model specification. We can make the crucial aid-policy interaction term significant, and by adding five observations (an extension of the sample by $2.1 \%$ ) we can also turn off this result. In addition, Burnside and Dollar depart from the other three third-generation studies in that they do not report any regressions with squared aid terms in their empirical estimations. They only include the aid-policy interaction term to capture polynomial effects in the aid-growth relationship. This is in contrast with the by now common result in empirical growth modelling, where squared terms appear as the rule rather than the exception. This is critical. The aid squared term is statistically significant and robust, while the same cannot be said about the aid-policy interactions term.

What general policy lessons can be drawn from this extensive literature? The Economist (26 June 1999) argues:

"Rich countries should be much more ruthless about how they allocate their largesse, whether earmarked or not. Emergency relief is one thing. But mainstream aid should be directed only to countries with sound economic management". (Emphasis added)

While the extreme view that aid only works in an environment of sound policy appears wrong, this is not to say that economic policies have no impact on the marginal productivity of aid. Yet, the world is heterogenous and noisy, and it may well be that many of those countries where aid works the best are, at the same time, among those that need foreign assistance the least. In contrast, countries that are less fortunate in having good policies in place, may need help badly to help bring them on track. They may need different 
forms of aid, but such real-world dilemmas remain unresolved. Single-cause explanations and mechanistic aid-allocation rules are not, for the time being, likely to be robust, and therefore useful guides to policy makers.

The third-generation work recognises that development is a complex process with interactions between economic and non-economic variables. The past decade has seen enormous changes in the world economic environment and the economic systems in place in many countries. Using past performance as an indicator of future performance is especially dubious in this environment, given the existing limited understanding of the interplay between aid, macroeconomic policy and political economy variables. In sum, the unresolved issue in assessing aid effectiveness is not whether aid works, but how and whether we can make the different kinds of aid instruments at hand work better in varying country circumstances. 


\section{Appendix A. Studies with Cross-Country Regression Results (Exogenous Aid) and Their Classification in Table 1}

[1] Ahmed, N. (1971), "A Note on the Haavelmo Hypothesis", Review of Economics and Statistics, LIII, 413-414.

[2] Areskoug, K. (1969), External Public Borrowing: Its Role in Economic Development. Praeger Publishers. $^{22}$

[3] Bornschier, V., Chase-Dunn, C., and Rubinson, V. (1978), "Cross-National Evidence of the Effects of Foreign Investment and Aid on the Economic Growth and Inequality: A Survey of Findings and a Re-analysis", American Journal of Sociology, 84(3), 651-683.

[4] Dowling, M. and Hiemenz, U. (1982), "Aid, Savings and Growth in the Asian Region", Economic Office Report Series 3, Asian Development Bank.

[5] Durbarry, R., Gemmell, N., and Greenaway, D. (1998), "New Evidence on the Impact of Foreign Aid on Economic Growth", Research Paper 98/8, Centre for Research in Economic Development and International Trade, University of Nottingham.

[6] Feyzioglu, T., Swaroop, V., and Zhu, M. (1998), "A Panel Data Analysis of the Fungibility of Foreign Aid", The World Bank Economic Review, 12(1), 29-58.

[7] Griffin, K. B. and Enos, J. L. (1970), "Foreign Assistance: Objectives and Consequences", Economic Development and Cultural Change, 18(3), 313-327.

[8] Griffin, K. B. (1970), "Foreign Capital, Domestic Savings and Economic Development", Bulletin of the Oxford University Institute of Economics \& Statistics, 32, 99-112.

[9] Gupta, K. L. and Islam, M. A. (1983), Foreign Capital, Savings and Growth - An International Cross-Section Study. D. Reidel Publishing Company, Dordrecht-Holland.

[10] Gupta, K. L. (1970), "Foreign Capital and Domestic Savings: A Test of Haavelmo's Hypothesis with Cross-Country Data: A Comment", Review of Economics and Statistics, LII, 214-216.

[11] Gupta, K. L. (1975), "Foreign Capital Inflows, Dependency Burden, and Saving Rates in Developing Countries: A Simultaneous Equation Model", Kyklos, 28, 358-374.

[12] Halevi, N. (1976), "The Effects on Investment and Consumption of Import Surpluses of Developing Countries", Economic Journal, 86, 853-858.

[13] Heller, P. S. (1975), "A Model of Public Fiscal Behavior in Developing Countries: Aid, Investment, and Taxation", American Economic Review, 65(3), 429-445.

[14] Khan, H. A. and Hoshino, E. (1992), "Impact of Foreign Aid on the Fiscal Behaviour of LDC Governments", World Development, 20(10), 1481-1488.

[15] Levy, V. (1987), "Does Concessionary Aid Lead to Higher Investment Rates in Low-Income Countries?", Review of Economics and Statistics, LXIX, 152-156.

[16] Levy, V. (1988), "Aid and Growth in Sub-Saharan Africa: The Recent Experience", European Economic Review, 32, 1777-1795.

[17] Massell, B. F., Pearson, S. R., and Fitch, J. B. (1972), "Foreign Exchange and Economic Development: An Empirical Study of Selected Latin American Countries", Review of Economics and Statistics, LIV, 208-212.

[18] Mosley, P., Hudson, J., and Horrell, S. (1987), "Aid, The Public Sector and The Market in Less Developed Countries", Economic Journal, 97, 616-641.

[19] Mosley, P., Hudson, J., and Horrell, S. (1992), "Aid, The Public Sector and The Market in Less Developed Countries : A Return to The Scene of The Crime", Journal of International Development, 4(2), 139-150.

[20] Over, A. M. (1975), "An Example of the Simultaneous-Equation Problem: A Note on Foreign Assistance: Objectives and Consequences", Economic Development and Cultural Change, 23, 751-756.

[21] Papanek, G. F. (1973), "Aid, Foreign Private Investment, Savings, and Growth In Less Developed

22 Areskoug (1973) has identical results, so the original regressions are used in what follows. 
Countries", Journal of Political Economy, 81(1), 120-130.

[22] Rahman, A. (1968), "Foreign Capital and Domestic Savings: A Test of Haavelmo's Hypothesis with Cross-Country Data", Review of Economics and Statistics, L, 137-138.

[23] Singh, R. D. (1985), "State Intervention, Foreign Economic Aid, Savings and Growth in LDCs: Some Recent Evidence", Kyklos, 38, 216-232.

[24]Snyder, D. W. (1990), "Foreign Aid and Domestic Savings: A Spurious Correlation?", Economic Development and Cultural Change, 39(1), 175-181.

[25] Snyder, D. W. (1993), "Donor Bias Towards Small Countries: An Overlooked Factor in The Analysis of Foreign Aid and Economic Growth", Applied Economics, 25, 481-488.

[26] Stoneman, C. (1975), "Foreign Capital and Economic Growth", World Development, 3(1), 11-26.

[27] Voivodas, C. S. (1973), "Exports, Foreign Capital Inflow and Economic Growth", Journal of International Economics, 3, 337-349.

[28] Weisskopf, T. E. (1972), "The Impact of Foreign Capital Inflow on Domestic Savings in Underdeveloped Countries", Journal of International Economics, 2, 25-38.

[29] White, H. (1992a), "What Do We Know About Aid's Macroeconomic Impact? An Overview of the Aid Effectiveness Debate", Journal of International Development, 4(2), 121-137.

The 131 regressions identified in the above studies, whose results are summarised in Table 1 in the main text, were classified as shown in Table A.1 below. Note that the first number in a parenthesis refers to the study as listed above, whereas subsequent numbers refer to our numbering of the typically more than one regression in a particular study. When no regression number is shown it is because the study in question only reports on one regression.

Table A.1. Classification of the 131 Regressions Summarised in Table 1

\begin{tabular}{|c|c|c|c|c|c|c|}
\hline $\begin{array}{l}\text { Exp. } \\
\text { Variable } \\
\text { Dep. var./ } \\
\text { Result }\end{array}$ & $(-)$ & A & $(+)$ & \multicolumn{3}{|c|}{ F } \\
\hline Savings & $\begin{array}{l}{[21: 1],[11: 2,} \\
3], \\
{[9: 3,4,10,13,14]} \\
,[23: 2,4], \\
{[24: 1],} \\
{[29: 1,2,3]}\end{array}$ & $\begin{array}{l}{[9: 2,8,9,11,12]} \\
,[23: 1,3], \\
{[24: 2,3],[29: 4]}\end{array}$ & & $\begin{array}{l}{[22],[8: 1],} \\
{[1: 1,2,4],} \\
{[28],} \\
{[21: 2,3],} \\
{[11: 1],} \\
{[9: 1,7]}\end{array}$ & $\begin{array}{l}{[10],[8: 2],} \\
{[1: 3],[9: 5,6]}\end{array}$ & [20] \\
\hline Savings* & [9:13] & $\begin{array}{l}{[21: 1],[11: 2],} \\
{[9: 2,3,4,8,9,10,} \\
11],[23: 1,3,4], \\
{[29: 1]}\end{array}$ & $\begin{array}{l}{[9: 9,12],[24: 1,2,3],} \\
{[29: 2,3,4]}\end{array}$ & & $\begin{array}{l}{[8: 2],} \\
{[1: 1,2,4],} \\
{[11: 1],} \\
{[9: 5,7]}\end{array}$ & $\begin{array}{l}{[22],[10],} \\
{[8: 1],} \\
{[1: 3],[28],} \\
{[21: 2,3],} \\
{[20],} \\
{[9: 1,6]}\end{array}$ \\
\hline Investment & & [17] & $\begin{array}{l}{[13],[12: 2],} \\
{[15: 1,2,3,4,5,6],} \\
{[16: 1,2,3,4],[14],} \\
{[6: 1,2]}\end{array}$ & & & {$[2],[12: 1]$} \\
\hline Growth & [18:2] & $\begin{array}{l}{[7: 1,2],[17: 2],} \\
{[24: 7],[26: 9],} \\
{[9: 16,17,18],} \\
{[23: 7,8],} \\
{[18: 1,3,4,5,6,7,} \\
8,10,11,12], \\
{[19: 2,3,4],} \\
{[29: 8],[24: 4]}\end{array}$ & $\begin{array}{l}{[24: 4,5,6],[24: 8],} \\
{[11: 5,6],} \\
{[26: 1,2,3,4,5,6,7,8],[27:} \\
10,11],[4 ; 1,2], \\
{[9: 15,19,20],[23: 5,6],} \\
{[18: 9,13],[16: 5,6],} \\
{[19: 1],[29: 5,6,7],} \\
{[24: 5,6],[5: 1,2,3,4,5]}\end{array}$ & & $\begin{array}{l}{[27],} \\
{[3: 1,2,3,4,5]}\end{array}$ & $\begin{array}{l}{[24: 9],} \\
{[11: 4]}\end{array}$ \\
\hline
\end{tabular}


Appendix B. Instrumental Variable Growth Regressions with Polynomial Effects of Aid and Policy

\begin{tabular}{|c|c|c|c|c|c|}
\hline \multicolumn{6}{|c|}{$\begin{array}{l}\text { Dependent variable: Growth rate of GDP per capita } \\
\text { Sample period: } 1974-93 \text {, Countries: } 56 \text {, Periods: } 5\end{array}$} \\
\hline Regression & 6 & 7 & 8 & 9 & 10 \\
\hline \multirow[t]{2}{*}{ Aid } & 0.142 & 0.055 & $0.236^{*}$ & $0.23 *$ & $0.265 * *$ \\
\hline & $(0.25)$ & (1.19) & $(1.75)$ & $(1.75)$ & $(2.00)$ \\
\hline \multirow[t]{2}{*}{ Aid x Policy } & 0.079 & -0.014 & -0.012 & & \\
\hline & $(1.61)$ & $(0.55)$ & $(0.42)$ & & \\
\hline \multirow[t]{2}{*}{$\operatorname{Aid}^{2}$} & & & $-0.005^{*}$ & $-0.005^{*}$ & $-0.005^{*}$ \\
\hline & & & $(1.70)$ & $(1.78)$ & $(1.81)$ \\
\hline \multirow[t]{2}{*}{ Policy $^{2}$} & & & 0.078 & & \\
\hline & & & $(0.77)$ & & \\
\hline \multirow[t]{2}{*}{ Openness } & $1.5^{* *}$ & $2.183 * *$ & 1.439 & $1.927 * *$ & $2.016 * *$ \\
\hline & $(2.24)$ & $(3.77)$ & $(1.33)$ & $(3.83)$ & $(3.86)$ \\
\hline \multirow{2}{*}{ Inflation } & -0.799 & $-1.372 * *$ & $-1.351 * *$ & $-1.168 * *$ & $-0.905^{*}$ \\
\hline & $(1.41)$ & $(2.68)$ & $(2.55)$ & $(2.55)$ & $(1.70)$ \\
\hline \multirow[t]{2}{*}{ Budget deficit } & 4.81 & $8.304 *$ & $8.195 *$ & $7.853^{*}$ & $8.851^{*}$ \\
\hline & $(0.89)$ & $(1.73)$ & $(1.67)$ & $(1.92)$ & (1.86) \\
\hline \multirow[t]{2}{*}{ Government cons. } & -2.878 & -3.825 & -5.848 & -5.04 & -3.964 \\
\hline & $(0.54)$ & $(0.76)$ & (1.10) & $(0.96)$ & $(0.71)$ \\
\hline \multirow[t]{2}{*}{ Financial depth } & 0.014 & 0.02 & 0.016 & 0.015 & 0.011 \\
\hline & $(0.95)$ & $(1.51)$ & (1.14) & (1.11) & $(0.75)$ \\
\hline \multirow[t]{2}{*}{ Institutional quality } & $0.727 * *$ & $0.624 * *$ & $0.717 * *$ & $0.722 * *$ & $0.76 * *$ \\
\hline & $(4.21)$ & $(3.81)$ & $(4.02)$ & $(4.08)$ & $(4.17)$ \\
\hline \multirow[t]{2}{*}{ Initial GDP per capita } & -0.111 & -0.163 & 0.041 & 0.038 & 0.098 \\
\hline & $(0.18)$ & $(0.27)$ & $(0.06)$ & $(0.06)$ & $(0.14)$ \\
\hline Obs. & 226 & 231 & 231 & 231 & 226 \\
\hline $\mathrm{R}^{2}$ & 0.39 & 0.39 & 0.40 & 0.39 & 0.39 \\
\hline
\end{tabular}

Note: A constant and time dummies are included in all regressions. Regressions 6 and 10 exclude five observations in accordance with the analysis in Burnside and Dollar (1997). The five observations are: Nicaragua (1986-89, 1990-93), Gambia (1986-89, 1990-93), and Guyana (1990-93). The $t$-statistics in parantheses are based on heteroskedasticity consistent standard errors. **, and * indicate significance at 5 and $10 \%$, respectively.

Instruments: arms import (lagged), dummy for Central American countries, dummy for Franc zone countries, dummy for Egypt, $\log$ (population), $\log (\text { population })^{2}, \log ($ population) x policy, $\log ($ infant mortality), $\log (\text { infant mortality })^{2}, \log$ (infant mortality) x policy, $\log$ (infant mortality $)^{2}$ x policy, Aid (lagged), Aid ${ }^{2}$ (lagged), Aid x policy (lagged), Aid $^{2}$ x policy (lagged). 


\section{References}

Aghion, P., and P. Howitt (1998). Endogenous Growth Theory. The MIT Press.

Ahmed, N. (1971). "A note on the Haavelmo hypothesis". Review of Economics and Statistics 53, 413-414.

Areskoug, K. (1969). External Public Borrowing: Its Role in Economic Development. Praeger Publishers.

Areskoug, K. (1973). "Foreign-capital utilization and economic policies in developing countries". Review of Economics and Statistics 55, 182-189.

Barro, R. J., N. G. Mankiw, and X. X. Sala-I-Martin (1995). "Capital mobility in neoclassical models of growth". American Economic Review 85, 103-115.

Barro, R. J. and X. X. Sala-I-Martin (1995). Economic Growth. McGraw-Hill, Inc.

Boone, P. (1994). "The impact of foreign aid on savings and growth". Mimeo, London School of Economics.

Boone, P. (1996). "Politics and the effectiveness of foreign aid". European Economic Review 40, 289-329.

Bornschier, V., C. Chase-Dunn, and V. Rubinson (1978). "Cross-national evidence of the effects of foreign investment and aid on the economic growth and inequality: A survey of findings and a reanalysis". American Journal of Sociology 84 (3), 651-683.

Browning, M., and A. Lusardi (1996). "Household saving: Micro theories and micro facts". Journal of Economic Literature 34 (4), 1797-1855.

Burnside, C. and D. Dollar (1997). "Aid, policies and growth". Policy Research Working Paper 1777, The World Bank, Development Research Group, Washington, D. C.

Cassen, R. (1994). Does Aid Work? (Second ed.). Clarendon Press, Oxford.

Chang, C. C., E. Fernandez-Arias, and L. Serven (1998). "Measuring Aid Flows: A New Approach". Mimeo, World Bank, Development Economics Research Group, Washington, DC.

Chenery, H. B. and A. M. Strout (1966). "Foreign assistance and economic development". American Economic Review 56, 679-733.

Dowling, M. and U. Hiemenz (1982). "Aid, savings and growth in the Asian region". Economic Office Report Series 3, Asian Development Bank.

Durbarry, R., N. Gemmell, and D. Greenaway (1998). "New evidence on the impact of foreign aid on economic growth". CREDIT Research Paper 98/8, Centre for Research in Economic Development and International Trade, University of Nottingham.

Feyzioglu, T., Swaroop, V., and Zhu, M. (1998), A Panel Data Analysis of the Fungibility of Foreign Aid", The World Bank Economic Review, 12(1), 29-58.

Griffin, K. B. and J. L. Enos (1970). "Foreign assistance: Objectives and consequences". Economic Development and Cultural Change 18(3), 313-327.

Griffin, K. B. (1970). "Foreign capital, domestic savings and economic development". Bulletin of the Oxford University Institute of Economics \& Statistics 32, 99-112.

Gupta, K. L. and M. A. Islam (1983). Foreign Capital, Savings and Growth. An International Cross-Section Study. International Studies in Economics and Econometrics. Dordrecht, Holland: D. Reidel Publishing Company.

Gupta, K. L. (1970). "Foreign capital and domestic savings: A test of Haavelmo's hypothesis with cross-country data: A comment". Review of Economics and Statistics 52, 214-216.

Gupta, K. L. (1975). "Foreign capital inflows, dependency burden, and saving rates in developing countries: A simultaneous equation model". Kyklos 28, 358-374.

Hadjimichael, M. T., D. Ghura, M. Mühleisen, R. Nord, and E. M. Uçer (1995). "Sub-Saharan Africa: Growth, savings, and investment, 1986-93". Occasional Paper 118, International Monetary Fund.

Halevi, N. (1976). "The effects on investment and consumption of import surpluses of developing countries". Economic Journal 86, 853-858.

Hansen, H., and F. Tarp (1999). "The Effectiveness of Foreign Aid". Mimeo, Development Economics Research Group, University of Copenhagen.

Heller, P. S. (1975). "A model of public fiscal behaviuor in developing countries: Aid, investment, and taxation". American Economic Review 65 (3), 429-445.

Khan, H. A. and Hoshino, E. (1992), "Impact of Foreign Aid on the Fiscal Behavior of LDC Governments", World Development, 20(10), 1481-1488.

Leamer, E. E. (1985). "Sensitivity analysis would help". American Economic Review 57, 308-313.

Levy, V. (1987) "Does Concessionary Aid Lead to Higher Investment Rates in Low-Income Countries?", 
Review of Economics and Statistics, LXIX, 152-156.

Levy, V. (1988)," Aid and Growth in Sub-Saharan Africa: The Recent Experience", European Economic Review, 32, 1777-1795.

Mankiw, N. G., D. Romer, and D. N. Weil (1992). "A contribution to the empirics of economic growth". Quarterly Journal of Economics 107, 407-438.

Massell, B. F., S. R. Pearson, and J. B. Fitch (1972). "Foreign exchange and economic development: An emperical study of selected Latin American countries". Review of Economics and Statistics 54, 208-212.

Masson, P. R., T. Bayoumi, and H. Samiei (1998). "International evidence on the determinants of private saving". World Bank Economic Review 12, 481-501.

McGillivray, M. and O. Morrissey (1998). "What do we know about the impact of aid on economic growth". Paper prepared for the CREDIT Tenth Anniversary Conference, University of Nottingham, 17 September 1998.

Michalopoulos, C. and V. Sukhatme (1989). "The impact of development assistance: A review of the quantitative evidence". In A. O. Krueger(Ed.), Aid and Development, Chapter 7, pp. 111-124. Baltimore, MD: Johns Hopkins University Press.

Mosley, P. (1980). "Aid, savings and growth revisited". Oxford Bulletin of Economics and Statistics 42, 79-95.

Mosley, P. (1987). Overseas Aid: Its Defense and Reform. Wheatsheaf Books.

Mosley, P., J. Hudson, and S. Horrell (1987). "Aid, the public sector and the market in less developed countries". Economic Journal 97, 616-641.

Mosley, P., J. Hudson, and S. Horrell (1992). "Aid, the public sector and the market in less developed countries : A return to the scene of the crime". Journal of International Development 4(2), 139-150.

Newlyn, W. T. (1973). "The effect of aid and other resource transfers on savings and growth in less developed countries: A comment". Economic Journal 83, 863-869.

Over, A. M. (1975). "An example of the simultaneous-equation problem: A note on foreign assistance: Objectives and consequences". Economic Development and Cultural Change 23, 751-756.

Papanek, G. F. (1972). "The effect of aid and other resource transfers on savings and growth in less developed countries". Economic Journal 82, 935-950.

Papanek, G. F. (1973). "Aid, foreign private investment, savings, and growth in less developed countries". Journal of Political Economy 81 (1), 120-130.

Rahman, A. (1968). "Foreign capital and domestic savings: A test of Haavelmo's hypothesis with cross-country data". Review of Economics and Statistics 50, 137-138.

Rosenstein-Rodan, P. (1961). "International aid for underdeveloped countries". Review of Economics and Statistics 43, 107-138.

Sala-i-Martin, X. X. (1997). "I just ran two million regressions". American Economic Review 87, 178-183.

Singh, R. D. (1985). "State intervention, foreign economic aid, savings and growth in LDCs: Some recent evidence". Kyklos 38, 216-232.

Snyder, D. W. (1990). "Foreign aid and domestic savings: A spurious correlation?" Economic Development and Cultural Change 39 (1), 175-181.

Snyder, D. W. (1993). "Donor bias towards small countries: An overlooked factor in the analysis of foreign aid and economic growth". Applied Economics 25, 481-488.

Stoneman, C. (1975). "Foreign capital and economic growth". World Development 3 (1), 11-26.

Tsikata, T. M. (1998). "Aid effectiveness: A survey of the recent empirical literature". International Monetary Fund, Policy and review Department.

Voivodas, C. S. (1973). "Exports, foreign capital in ow and economic growth". Journal of International Economics 3, 337-349.

Weisskopf, T. E. (1972). "The impact of foreign capital inflow on domestic savings in underdeveloped countries". Journal of International Economics 2, 25-38.

White, H. (1992a). "The macroeconomic impact of development aid: A critical survey". Journal of Development Studies 28 (2), 163-240.

White, H. (1992b). "What do we know about aid's macroeconomic impact? An overview of the aid effectiveness debate". Journal of International Development 4 (2), 121-137.

World Bank (1998). Assessing Aid. What Works, What Doesn't, and Why. World Bank Policy Research Report. Oxford University Press. 